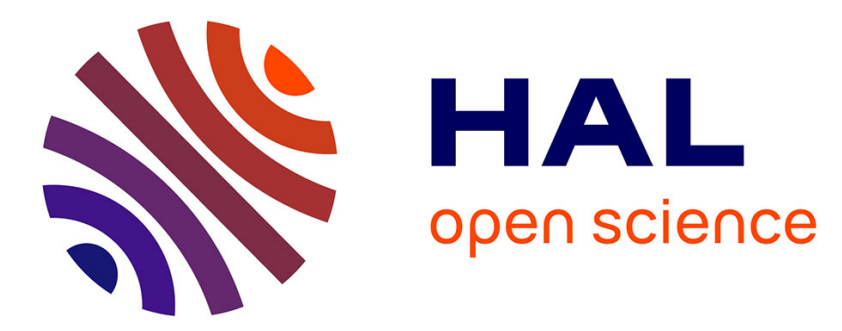

\title{
Non mammalian vertebrate models and the endocannabinoid system: relationships with gonadotropin-releasing hormone
}

Rosanna Chianese, Gilda Cobellis, Riccardo Pierantoni, Silvia Fasano, Rosaria Meccariello

\section{To cite this version:}

Rosanna Chianese, Gilda Cobellis, Riccardo Pierantoni, Silvia Fasano, Rosaria Meccariello. Non mammalian vertebrate models and the endocannabinoid system: relationships with gonadotropin-releasing hormone. Molecular and Cellular Endocrinology, 2008, 286 (1-2), 10.1016/j.mce.2008.01.009 . hal00531983

\section{HAL Id: hal-00531983 \\ https://hal.science/hal-00531983}

Submitted on 4 Nov 2010

HAL is a multi-disciplinary open access archive for the deposit and dissemination of scientific research documents, whether they are published or not. The documents may come from teaching and research institutions in France or abroad, or from public or private research centers.
L'archive ouverte pluridisciplinaire HAL, est destinée au dépôt et à la diffusion de documents scientifiques de niveau recherche, publiés ou non, émanant des établissements d'enseignement et de recherche français ou étrangers, des laboratoires publics ou privés. 


\section{Accepted Manuscript}

Title: Non mammalian vertebrate models and the endocannabinoid system: relationships with gonadotropin-releasing hormone

Authors: Rosanna Chianese, Gilda Cobellis, Riccardo Pierantoni, Silvia Fasano, Rosaria Meccariello

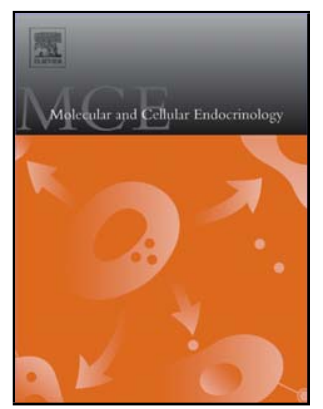

PII: S0303-7207(08)00016-6

DOI: doi:10.1016/j.mce.2008.01.009

Reference: MCE 6794

To appear in: $\quad$ Molecular and Cellular Endocrinology

Received date: $\quad 14-12-2007$

Revised date: $\quad 18-1-2008$

Accepted date: $\quad 18-1-2008$

Please cite this article as: Chianese, R., Cobellis, G., Pierantoni, R., Fasano, S., Meccariello, R., Non mammalian vertebrate models and the endocannabinoid system: relationships with gonadotropin-releasing hormone, Molecular and Cellular Endocrinology (2007), doi:10.1016/j.mce.2008.01.009

This is a PDF file of an unedited manuscript that has been accepted for publication. As a service to our customers we are providing this early version of the manuscript. The manuscript will undergo copyediting, typesetting, and review of the resulting proof before it is published in its final form. Please note that during the production process errors may be discovered which could affect the content, and all legal disclaimers that apply to the journal pertain. 
Non mammalian vertebrate models and the endocannabinoid system: relationships with gonadotropin-releasing hormone.

Rosanna Chianese, Gilda Cobellis, Riccardo Pierantoni, Silvia Fasano, Rosaria Meccariello*, Dipartimento di Medicina Sperimentale, Sez. “F. Bottazzi”, II Università di Napoli, Naples, Italy.

${ }^{1}$ Dipartimento di Studi delle Istituzioni e dei Sistemi Territoriali, Università di Napoli "Parthenope", Naples, Italy.

*Corresponding author: Rosaria Meccariello, Dipartimento di Studi delle Istituzioni e dei Sistemi Territoriali, Università di Napoli "Parthenope", via Medina 40, 80133, Naples, Italy; phone: +39081 5665840; fax: +39 081 5667536; e-mail address: rosaria.meccariello@uniparthenope.it 


\begin{abstract}
Endocannabinoids, via cannabinoid receptors (CB1 and $\mathrm{CB} 2)$, affect reproductive functions at both local and central level. Due to the high complexity of the endocannabinoid system, to the widespread distribution outside the nervous system and to the high degree of evolutionary conservation, a deep CB1 molecular characterization among species may be useful to elucidate the activity of endocannabinoids at multiple levels. In this review we report CB1 characterization in non mammalian animal models and, in particular, in the anuran amphibian, the frog, Rana esculenta; we also describe its expression during the annual sexual cycle. Moreover, since reproductive functions are under control of gonadotropin releasing hormone $(\mathrm{GnRH}), c b 1 \mathrm{mRNA}$ and protein expression profile in the forebrain has been compared to those of GnRH-I, the mammalian form primarily involved in gonadotropin release.
\end{abstract}

Running title: $c b 1$ in non mammalian animal models

Key words: cannabinoid receptor, amphibians, vertebrates, post transcriptional modifications, GnRH

\title{
Content
}

1) Introduction

2) Cloning of $c b 1$ in R.esculenta

3) $\mathrm{Cb} 1$ and GnRH-I relationship in the frog, R.esculenta.

4) Closing remarks

5) References

\section{1) Introduction}

Biological systems generally produce endocannabinoids, endogenous lipidic mediators [i.e. anandamide (arachidonoylethanolamide, AEA), 2-arachidonoyl glycerol (2-AG), the noladin ether 
(2-arachidonyl glyceryl ether, 2-AGE), virodhamine (o-arachidonoylethalamine), oleoylethanolamide (OEA), palmitoylethanolamide (PEA)], and possess at least three cannabinoid receptors. Type 1 and type 2 cannabinoid receptors (respectively CB1 and CB2), classical seven trans-membrane G-protein coupled receptors, are highly expressed in the central nervous system and in the immune system, respectively. Both are also expressed in several tissues, gonads included (Brown et al., 2002, Galiegue et al., 1995, Matsuda 1990, Shire et al., 1996). The type-1 vanilloid receptor (TRPV1), may be considered the third cannabinoid receptor; it is a ligand-gated and non-selective cationic channel with an intracellular binding site for the AEA; and is expressed at both central and local level (Di Marzo et al., 2002, van der Stelt et al., 2005, Wang et al., 2006).

Besides CB1 and CB2, the presence of CBx has been postulated in mice (Wiley and Martin 2002); recently, the orphan receptors GPR55 and GPR119 have been considered putative novel cannabinoid receptors (Brown 2007); the former is activated by multiple different cannabinoid ligands (Brown 2007), the latter binds the acylethanolamides OEA (Overton et al., 2006)

Although endocannabinoids are lipidic compounds, a putative endocannabinoid membrane transporter (EMT) mediates the uptake of AEA and 2-AG according to a saturable, selective and temperature dependent process (Hillard and Jarrahian 2000).

Generally endocannabinoids, cannabinoid receptors, EMT and several enzymes responsible for endocannabinoid biosynthesis and degradation constitute the highly conserved “endocannabinoid system".

Focusing on cannabinoid receptors, orthologs of the human $c b 1$ have been cloned and sequenced in vertebrates, from fish to mammals (Elphick and Egertovà 2001). Two paralog genes, $c b 1$ and $c b 2$ have been detected in mammals. In addition, in humans, two splice variants of $c b 1$, $c b 1 a$ and $c b 1 b$, produce proteins with different amino terminal domain, pharmacological effects and expression rate (Ryberg et al., 2005, Shire et al., 1995). In fish, three paralog genes with differential tissue expression have been detected; in the puffer fish, Fugu rubripes, two cbl genes, $c b 1 A$ and $c b 1 B$, (Yamaguchi et al., 1996) together with a $c b 2$ gene have been cloned; in the 
zebrafish, Danio rerio, a $c b 1$ gene and paired paralogs of $c b 2$ genes, $c b 2 a$ and $c b 2 b$, have recently been described (Rodriguez-Martin et al., 2007). In invertebrates, $c b$ ortholog genes have been cloned in the urochordate, the sea squirt Ciona intestinalis (Elphick et al., 2003), and later in the cephalochordate, the amphioxus, Branchiostoma floridae (Elphick 2007). The current evolutionary hypothesis correlates the first appearance of cannabinoid system to deuterostomian organisms (Elphick and Egertovà 2001, Salzet and Stefano 2002 for reviews). Nevertheless, in the sea urchin Strongylocentrotus purpuratus, a non-chordate deuterostomian invertebrate in which endocannabinoid affect sperm functions (Chang et al., 1993, Schuel et al., 1994, Schuel and Burkman 2005), the search of a $c b 1 / c b 2$ orthologs has been carried out without any success (Burke et al., 2006).

Endocannabinoids modulate reproductive functions at multiple levels (Wang et al., 2006). At central level, they negatively affect the secretion of pituitary gonadotropin hormones (LH and FSH); such effect is not mediated at pituitary level but upstream at hypothalamic level (for review Murphy et al., 1998, Wang et al., 2006, Wenger et al., 2001). CB1 activity has also been reported in the anterior pituitary gland in mammals and in amphibians (Wenger et al., 1999, Cesa et al., 2002) and CB1 immunoreactivity has been detected in lactotrophs and gonadotrophs (Wenger et al., 1999, Cesa et al., 2002). Lastly, in vitro AEA regulates adenohypophysis hormonal secretion of prolactin, LH, ACTH and GH in dispersed rat pituitary cells (Wenger et al., 2000). At local level, in males, endocannabinoids control sperm motility and or acrosomic reaction in human (Rossato et al., 2005, Schuel et al., 2002), boar (Maccarrone et al., 2005), mouse (Ricci et al., 2007), frog (Cobellis et al., 2006) and sea urchin (Chang et al., 1993, Schuel et al., 1994, Schuel and Burkman 2005). A reduction in copulatory behaviour has also been described (Wang et al., 2006). In females, they control ovulation, implantation, early embryonic development, as well as foetal growth and number of pregnancies carried to term, the onset of parturition and milk ejections during lactation (for review Wang et al., 2006). Interestingly, AEA, via CB1, acts as a retrograde messenger and inhibits the neuronal neurotransmitter release at central level and the 
polispermy at local level (Schuel and Burkman 2005 for review). Nevertheless, a complete and clear picture of the signalling evoked by endocannabinoid system at both central and local level is still missing.

A comparative approach has been recognized to gain a deep insight on adaptative phenomena leading to evolutionarily track as well as providing an insight into physiological mechanisms in building general models. Simply to cite an example, the first experiments of nuclei transplantation were conducted using frog eggs (Briggs and King 1952). Besides evolutionary speculations, one of the advantage of non-mammalian vertebrate in the study of reproductive function, in that most of them are seasonal breeders with a physiological switch on/off of gonadic activity. Environmental factors such as temperature and photoperiods deeply control reproductive functions; both can easily be modified in laboratory, leading to a controlled suppression and/or induction of reproductive functions. Lastly, both gonad and brain architecture are simpler than mammals and this might facilitate morpho-functional studies. Indeed, non-mammalian vertebrates have been recognized to possess morphological features to better study relationships between different neurotransmitter-neuroendocrine-paracrine systems (Teresawa 2003, Pierantoni et al 2002a). In this respect, the use of experimental model other than mammals might be useful to elucidate some functional aspects of endocannabinoid system.

In the recent years, we have characterized a complete cannabinoid system in the anuran amphibian, the frog, Rana esculenta (Cobellis et al., 2006, Meccariello et al., 2006, 2007). This animal model is a seasonal breeder and has the following advantages; 1) a slow progression of spermatogenesis with germ cells at the same maturative stage appearing in specific periods of the annual sexual cycle; 2) a simple testis morphology characterized by germ cells at the same maturative stage that develop in germinal cysts (Rastogi et al., 1976, Pierantoni et al., 2002b); 3) cyclic hormonal fluctuations associated to the progression of spermatogenesis.

\section{2) Cloning of $c b 1$ in R.esculenta}


In R.esculenta we have cloned a partial $c b 1$ cDNA fragment $(f c b 1)$ comprising a complete coding region of 1389 bp encoding a protein of 462 amino acidic residues. High nucleotide (62.6 to $81.9 \%$ ) and amino acidic identity (61.9 to $88.1 \%)$ with the other vertebrate known $c b 1$ has been observed. Critical domains for the receptor functionality are conserved in FCB1 protein. The lowest nucleotide/amino acidic identity is observed in the $5 \% \mathrm{~N}$-terminal region of the receptor (amino acidic residues 1-72); a sub domain of seven amino acidic residues is completely lost in R.esculenta (Fig 1).

Interestingly, in $R$. esculenta, detection of nucleotide differences among brain/testis cDNA and genomic sequences in codons 5, 30, 70, 186, 252 and 408 together with the corresponding amino acidic variations in codons 70 and 408 has been reported (Meccariello et al., 2007). Since such studies were performed comparing cDNA and genomic sequences from the same pools of frog tissues collected during the annual sexual cycle, possibility of polymorphic sites should be excluded. By contrast, different cDNA sequences in brain and testis, together with differential RNA folding, might indicate that post translational modifications affect $c b 1$ RNA stability and viability.

In humans, single nucleotide polymorphisms (SNPs) have been reported for $c b 1$ (Zhang et al., 2004, Muller et al., 2007), cb2 (Karsak et al ., 2005) and faah (Sipe et al., 2002), a fatty acid amide hydrolase responsible for AEA degradation to ethanolamine and arachidonic acid. Obesity, schizophrenia, alcohol dependence and striatal responses to happy faces have been associated to one of the four known cb1 SNPs (Russo et al., 2007, Tsai et al., 2000, Martinez-Gras et al., 2007, Schmidt et al., 2002); osteoporosis and systolic/diastolic blood pressure have been associated to cb2 SNPs (Arg528Lys) (Karsak et al., 2005, Yamada et al., 2007); lastly, substance abuse / dependence in Caucasian population, higher body mass index and fat metabolism have been correlated to C385A faah SNP responsible for the missense mutation Pro129Thr (Sipe et al., 2002, Aberle et al., 2007). 
Comparison between the $c b 1$ genomic sequences and the corresponding cDNA sequences available in GenBank confirms that nucleotide changes in $c b 1$ also occur in fish and mammals. However, as in frog, most changes do not influence the amino acidic composition except in Fugu rubripes $c b 1 b$ gene. In this case, nucleotide changes in codons 241 and 463 affect the amino acidic composition (A241E and D463A). Worth of note, since there is no evidence that genomic and cDNA sequences deposited in Gene Bank derive from the same animal collections, the hypothesis that, besides SNPs, post translational modifications of $c b 1$ might currently occur in vertebrates. This hypothesis is quite suggestive and needs further investigations.

\section{3) $\mathrm{Cb} 1$ and $G n R H-I$ relationship in the frog, R.esculenta.}

As in other vertebrates, besides central nervous system, $c b 1$ is widely expressed in frog tissues, gonads included (Meccariello et al., 2006). Fluctuations of $c b 1$ expression level have been reported in both testis and brain during the annual sexual cycle (Cobellis et al., 2006, Meccariello et al., 2006). In testis, $c b 1$ expression peaks in autumn, when spermiogenesis takes place, and in early spring as soon as spermatogenesis resumes and sperm release occurs. Such expression profiles clearly correlate with plasmatic androgen levels (d'Istria et al., 1974, Cobellis et al., 1997) and with the appearance of $\mathrm{CB} 1$ and FAAH in tubular compartment, mainly in post meiotic germ cells (elongating spermatids and spermatozoa) (Cobellis et al., 2006); possibility of an androgen dependent $c b 1$ expression should be addressed. Frog spermatozoa express both CB1 and FAAH; as in human, boar and sea urchin, also in frog AEA modulates sperm motility (Schuel et al., 1994, 2002, Maccarrone 2005, Cobellis et al., 2006) indicating an evolutionarily conserved role in the regulation of male reproductive functions.

AEA and $\Delta^{9}$-tetrahydrocannabinol (THC), a phytocannabinoid known as the active constituent of the marijuana plant Cannabis sativa, exerts a negative effect of on neuroendocrine regulation of pituitary hormone secretion inhibiting the release of hypothalamic GnRH (Murphy et al., 1998, Scorticati et al., 2004). CB1 is located in the anterior preoptic area and hypothalamus 
(Matsuda et al., 1993), brain areas where the GnRH neurons reside. Immortalized GT1 neurons, in turn, produce endocannabinoids, express CB1 and also CB2 (Gammon et al., 2005); in vivo GnRH secreting neurons are closely located to cannabinergic neurons and scantly express $c b 1$. It is still unclear whether endocannabinoid exert their effects directly on GnRH neurons or on neighbouring cells that control GnRH release. To gain further insight concerning the involvement of cannabinergic system on reproductive functions at central level, we took advantage of the frog brain, a laminate structure with a discrete localization of neuronal population. In this respect, we compared GnRH-I, the molecular form mainly described as hypophysiotropic (Pierantoni et al, 2002a), and CB1 fluctuations in the forebrain during the annual sexual cycle. GnRH-I massive synthesis occurs in the forebrain from April to September, when the decapeptide accumulates in the brain, and reaches a minimal expression level in December- March (Fig.2A), when the peptide is released (Di Matteo et al., 1996) to sustain gonadotropin discharge (Polzonetti et al., 1998). During the annual sexual cycle, in the same encephalic area, $c b 1$ mRNA fluctuations are opposite as compared to GnRH-I mRNA (Fig.2B), except in September, when $c b 1$ high expression level is available in the telencephalon (Meccariello et al., 2006). Such cbl expression profile well correlates with CB1 protein level reported in Fig.3.

Annual fluctuations of global CB1 content in telencephalon and diencephalon have been assayed by Western blot using an antibody against rat C-terminus CB1 raised in rabbit (WagerMiller et al., 2002). In telencephalon the global amount of CB1 protein mirrors $c b 1$ expression profile, with two expression peaks in September and March (Meccariello et al., 2006). By contrast, in diencephalon, $\mathrm{CB} 1$ protein and mRNA are quite overlapped except in December, when high expression level corresponds to minimal protein level (Meccariello et al., 2006). Since in our experiments diencephalons were not collected in January -February, it is not excluded the possibility of a protein peak in middle winter.

In conclusion, a general view indicates that GnRH release correlates with the minimal levels of CB1 detected in both telencephalon and, expecially, in the diencephalon, the encephalic 
area mainly devoted to the control of reproductive functions. In this respect, an involvement of cannabinergic system in GnRH-I circuitry might be postulated.

\section{4) Closing remarks}

The use of R.esculenta in the study of the endocannabinoid system once again confirms that basic mechanisms are highly conserved in evolution. Nevertheless, the evidence of synonymous and non synonymous differences between $c b 1$ cDNA and genomic DNA sequences detected in frogs might be useful for pharmacological applications, if confirmed in humans. Interestingly, such nucleotide changes also occur in other vertebrates, from fish to mammals. Whether or not such phenomenon is due to post translational modifications or to SNPs should be further investigated; a clear point is that $c b 1$ nucleotide changes in humans are often associated to behavioural/neurological diseases. It is not excluded that such changes might also be linked to hydiopatic infertility.

Furthermore, this experimental model may help to solve several intriguing questions related to the basic information on endocannabinoid system, especially regarding the control of reproductive functions. Indeed, besides the negative effect of endocannabinoids on GnRH and LH secretion, in rat, GnRH neurons are closely located to cannabinergic neurons and scantly express cbl (Gammon et al., 2005). Thanks to the feature of the frog as seasonal breeder, GnRH-I mRNA and peptide expression profile has been compared to $c b 1$ mRNA and protein expression profile indicating that a physiological reverse relationship might exist between the two systems. In this respect, the possibility that cannabinergic neurons may exert a feedback control on GnRH neuron functionality should be further investigated. At present, we report the existence of a negative relationship between GnRH-I and CB1 expression in a lower vertebrate species indicating the possibility of the existence of an evolutionarily conserved mechanism exerted by the endocannabinoid system in the control of GnRH synthesis and /or discharge. 


\section{5) References}

Aberle, J., Fedderwitz, I., Klages, N., George, E., Beil, F.U., 2007. Genetic variation in two proteins of the endocannabinoid system and their influence on body mass index and metabolism under low fat diet. Horm. Metab. Res. 39, 395-397.

Briggs, R., King, T.J., 1952. Transplantation of Living Nuclei From Blastula Cells into Enucleated Frogs' Eggs. Proc. Natl. Acad. Sci. USA 38, 455-463.

Brown, A.L., 2007. Novel cannabinoid receptors.Br. J. Pharmacol. 152, 567-575.

Brown, S.M., Wager-Miller, J., Mackie, K., 2002. Cloning and molecular characterization of the rat CB2 cannabinoid receptor. Biochim. Biophys. Acta 1576, 255-264.

Burke, R.D., Angerer, L.M., Elphick, M.R., Humphrey, G.W., Yaguchi, S., Kiyama, T., Liang, S., Mu, X., Agca, C., Klein, W.H., Brandhorst, B.P., Rowe, M., Wilson, K., Churcher, A.M., Taylor, J.S., Chen, N., Murray, G., Wang, D., Mellott, D., Olinski, R., Hallböök, F., Thorndyke, M.C., 2006. A genomic view of the sea urchin nervous system. Dev. Biol. 300, 434-460.

Cesa, R., Guastalla, A., Cottone, E., Mackie, K., Beltramo, M., Franzoni, MF., 2002. Relationships between CB1 cannabinoid receptors and pituitary endocrine cells in Xenopus laevis: an immunohistochemical study. Gen. Comp. Endocrinol. 25, 17-24.

Chang, M.C., Berkery, D., Schuel, R., Laychock, S.G., Zimmerman, A.M., Zimmerman, S., Schuel H., 1993.Evidence for a cannabinoid receptor in sea urchin sperm and its role in blockade of the acrosome reaction. Mol. Reprod. Dev. 36, 507-516.

Cobellis, G., Pierantoni, R., Fasano, S., 1997. c-fos- and c-jun-like mRNA expression in frog (Rana esculenta) testis during the annual reproductive cycle. Gen. Comp. Endocrinol. $106,23-29$.

Cobellis, G., Cacciola, G., Scarpa, D., Meccariello, R., Chianese, R., Franzoni, M.F., Mackie, K., Pierantoni, R., Fasano, S., 2006. Endocannabinoid system in frog and rodent testis: 
type-1 cannabinoid receptor and fatty acid amide hydrolase activity in male germ cells. Biol. Reprod. 75, 82-89.

Di Marzo, V., De Petrocellis, L., Fezza, F., Ligresti, A. Bisogno, T., 2002. Anandamide receptors. Prostaglandins Leukot. Essent. Fatty Acids 66, 377-391.

Di Matteo, L., Vallarino, M., Pierantoni, R., 1996. Localization of GnRH molecular forms in the brain, pituitary, and testis of the frog, Rana esculenta. J. Exp. Zool. 274, 33-40.

d'Istria, M., Delrio, G., Botte, V., Chieffi, G.,. 1974. Radioimmunoassay of testosterone, 17betaoestradiol and oestrone in the male and female plasma of plasma of Rana esculenta during sexual cycle. Steroids Lipids Res. 5, 42-48.

Elphick, M.R., Egertovà, M., 2001. The neurobiology and evolution of cannabinoid signalling. Philos. Trans. R. Soc. Lond. B Biol. Sci. 356, 381-408.

Elphick, M.R., Satou, Y., Satoh, N., 2003. The invertebrate ancestry of endocannabinoid signalling: an orthologue of the vertebrate cannabinoid receptors in the urochordate Ciona intestinalis. Gene 302, 95-101.

Elphick, M.R., 2007. BfCBR: a cannabinoid receptor ortholog in the cephalochordate Branchiostoma floridae (Amphioxus). Gene 399, 65-71.

Galiegue, S., Mary, S., Marchand, J., Dussossoy, D., Carriere, D., Carayon, P., Bouaboula, M., Shire, D., Le Fur, G, Casellas, P., 1995. Expression of central and peripheral cannabinoid receptors in human immune tissues and leukocyte subpopulations. Eur. J. Biochem. 232, 54-61.

Gammon, C.M., Freeman, G.M. Jr, Xie, W., Petersen, S.L., Wetsel, W.C., 2005. Regulation of gonadotropin-releasing hormone secretion by cannabinoids. Endocrinology 46, 4491-9

Hillard, C.J., Jarrahian, A., 2000. The movement of N-arachidonoylethanolamine (anandamide) across cellular membranes. Chem. Phys. Lipids 108, 123-134.

Karsak, M., Cohen-Solal, M., Freudenberg, J., Ostertag, A., Morieux, C., Kornak, U., Essig, J., Erxlebe, E., Bab, I., Kubisch, C., de Vernejoul, M.C., Zimmer, A., 2005. Cannabinoid 
receptor type 2 gene is associated with human osteoporosis. Hum. Mol. Genet. 14, 33893396.

Maccarrone M, Barboni B, Paradisi A, Bernabò N, Gasperi V, Pistilli MG, Fezza F, Lucidi P, Mattioli M. 2005. Characterization of the endocannabinoid system in boar spermatozoa and implications for sperm capacitation and acrosome reaction. J. Cell. Sci. 118, 43934404.

Martínez-Gras, I., Hoenicka, J., Ponce, G., Rodríguez-Jiménez, R., Jiménez-Arriero, M.A., Pérez-Hernandez, E., Ampuero, I., Ramos-Atance, J.A., Palomo, T., Rubio, G., 2006. (AAT)n repeat in the cannabinoid receptor gene, CNR1: association with schizophrenia in a Spanish population. Eur. Arch. Psychiatry Clin. Neurosci. 256, 437-441.

Matsuda, L.A., Lolait, S.J., Brownstain, M.J., Young, A.C., Bonner, T.I., 1990 Localization of cannabinoid receptor mRNA in rat brain. J. Comp. Neurol. 346, 561-564.

Meccariello, R., Chianese, R., Cacciola, G., Cobellis, G., Pierantoni, R., Fasano, S. 2006 Type-1 cannabinoid receptor expression in the frog, Rana esculenta, tissues: a possible involvement in the regulation of testicular activity. Mol. Reprod. Dev. 73, 551-558.

Meccariello, R., Chianese, R., Cobellis, G., Pierantoni, R., Fasano, S., 2007. Cloning of type 1 cannabinoid receptor in Rana esculenta reveals differences between genomic sequence and cDNA. FEBS J. 274, 2909-2920.

Müller, T.D., Reichwald, K., Wermter, A.K., Brönner, G., Nguyen, T.T., Friedel, S., Koberwitz, K., Engeli, S., Lichtner, P., Meitinger, T., Schäfer, H., Hebebrand, J., Hinney, A., 2007. No evidence for an involvement of variants in the cannabinoid receptor gene (CNR1) in obesity in German children and adolescents. Mol. Genet. Metab. 90, 429-434.

Murphy, L.L., Munoz, R.M., Adrian, B.A., Villanua, M.A. 1998. Function of cannabinoid receptors in the neuroendocrine regulation of hormone secretion. Neurobiol. Dis. 5, 432446. 
Overton, H.A., Babbs, A.J., Doel, S.M., Fyfe, M.C., Gardner, L.S., Griffin, G., Jackson, H.C., Procter, M.J., Rasamison, C.M., Tang-Christensen, M., Widdowson, P.S., Williams, G.M., Reynet, C., 2006. Deorphanization of a G protein-coupled receptor for oleoylethanolamide and its use in the discovery of small-molecule hypophagic agents. Cell. Metab. 3, 167-175.

Pierantoni R., Cobellis G, Meccariello R, Fasano S. 2002a. Evolutionary aspects of cellular communication in the vertebrate hypothalamo-hypophysio-gonadal axis. Int. Rev. Cytol. 218, 69-141.

Pierantoni, R., Cobellis, G., Meccariello, R., Palmiero, C., Fienga, G., Minucci, S., Fasano, S., 2002b. The amphibian testis as model to study germ cell progression durino spermatogenesis. Comp. Biochem. Physiol. B Biochem. Mol. Biol. 132, 131-139.

Polzonetti-Magni, A.M., Mosconi, G., Carnevali, O., Yamamoto, K., Hanaoka, Y., Kikuyama, S., 1998. Gonadotropins and reproductive function in the anuran amphibian, Rana esculenta. Biol. Reprod. 58, 88-93.

Rastogi, R.K., Iela, L., Saxena, P.K., Chieffi, G., 1976. The control of spermatogenesis in the green frog, Rana esculenta. J. Exp. Zool. 169, 151-166.

Ricci, G., Cacciola, G., Altucci, L., Meccariello, R., Pierantoni, R., Fasano, S., Cobellis, G., 2007. Endocannabinoid control of sperm motility: the role of epididymus. Gen. Comp. Endocrinol. 153, 320-322

Rodriguez-Martin, I., Herrero-Turrion, M.J., Marron Fdez de Velasco, E., Gonzalez-Sarmiento, R., Rodriguez, R.E., 2007. Characterization of two duplicate zebrafish Cb2-like cannabinoid receptors. Gene 389, 36-44.

Rossato, M., Ion Popa, F., Ferigo, M., Clari, G., Foresta, C. 2005. Human sperm express cannabinoid receptor $\mathrm{Cb} 1$, the activation of which inhibits motility, acrosome reaction, and mitochondrial function. J. Clin. Endocrinol. Metab. 90, 984-991.

Russo, P., Strazzullo, P., Cappuccio, F.P., Tregouet, D.A., Lauria, F., Loguercio, M., Barba, G., Versiero, M., Siani, A., 2007. Genetic variations at the endocannabinoid type 1 receptor 
gene (CNR1) are associated with obesity phenotypes in men. J. Clin. Endocrinol. Metab. 92, 2382-2386.

Ryberg, E., Vu, H.K., Larsson, N., Groblewski, T., Hjorth, S., Elebring, T., Sjogren, S., Greasley, P.J., 2005. Identification and characterization of a novel splice variant of the human CB1 receptor. FEBS Lett. 57, 259-264.

Salzet, M., Stefano, G.B., 2002. The endocannabinoid system in invertebrates. Prostaglandins Leukot. Essent. Fatty Acids 66, 353-361.

Schmidt, L.G., Samochowiec, J., Finckh, U., Fiszer-Piosik, E., Horodnicki, J., Wendel, B., Rommelspacher, H., Hoehe, M.R., 2002. Association of a CB1 cannabinoid receptor gene (CNR1) polymorphism with severe alcohol dependence. Drug Alcohol Depend. 65, 221224.

Schuel, H., Goldstein, E., Mechoulam, R., Zimmerman, A.M., Zimmerman, S., 1994. Anandamide (arachidonylethanolamide), a brain cannabinoid receptor agonist, reduces sperm fertilizing capacity in sea urchins by inhibiting the acrosome reaction. Proc. Natl. Acad. Sci. USA 91, 7678-7682.

Schuel, H., Burkman, L.J., Lippes, J., Crickard, K., Mahony, M.C., Giuffrida, A., Picone, R.P., Makriyannis, A.,. 2002. Evidence that anandamide-signalling regulates human sperm functions required for fertilization. Mol. Reprod. Dev. 63, 376-387.

Schuel. H., Burkman, L.J., 2005. A tale of two cells: endocannabinoid-signaling regulates functions of neurons and sperm. Biol. Reprod. ;73, 1078-1086.

Scorticati, C., Fernandez-Solari, J., De Laurentiis, A., Mohn, C., Prestifilippo, J.P., Lasaga, M., Seilicovich, A., Billi, S., Franchi, A., McCann, S., Rettori, V. 2004. The inhibitory effect of anandamide on luteinizing hormone-releasing hormone secretion is reversed by estrogen. Proc. Natl. Acad. Sci. USA 32, 11891-11896. 
Shire, D., Carillon, C., Kaghad, M., Calandra, B., Rinaldi-Carmona, M., Le Fur, G., Caput, D, Ferrara, P., 1995. An amino-terminal variant of the central cannabinoid receptor resulting from alternative splicing. J. Biol. Chem. 270, 3726-3731.

Shire, D., Calandra, B., Rinaldi-Carmona, M., Oustric, D., Passegue, B., Bonnin-Cabanne, O., Le Fur, G., Caput, D., Ferrara, P. 1996. Molecular cloning, expression and function of the murine CB2 peripheral cannabinoid receptor. Biochim. Biophis. Acta 1307, 132-136

Sipe, J.C., Chiang, K., Gerber, A.L., Beutler, E., Cravatt, B.F., 2002. A missense mutation in human fatty acid amide hydrolase associated with problem drug use. Proc. Natl. Acad. Sci. USA. $99,8394-8399$

Terasawa, E. 2003 Gonadotropin-releasing hormone II: is this neuropeptide important for mammalian reproduction? Endocrinology 144, 3-4

Tsai, S.J., Wang, Y.C., Hong, C.J., 2000 Association study of a cannabinoid receptor gene (CNR1) polymorphism and schizophrenia. Psychiatr. Genet. 10, 149-151.

van der Stelt, M., Trevisani, M., Vellani, V., De Petrocellis, L., Schiano Moriello, A., Campi, B., McNaughton, P., Geppetti, P., Di Marzo, V., 2005. Anandamide acts as an intracellular messenger amplifying Ca2+ influx via TRPV1 channels. EMBO J. 24, 3517-3528.

Yamada, Y., Ando, F., Shimokata, H., 2007. Association of gene polymorphisms with blood pressure and the prevalence of hypertension in community-dwelling Japanese individuals. Int. J. Mol. Med. 19, 675-683.

Yamaguchi, F., Macrae, A.D., Brenner, S., 1996. Molecular cloning of two cannabinoid type 1like receptor genes from the puffer fish Fugu rubripes. Genomics 35, 603-605.

Wager-Miller J, Westenbroek R, Mackie K. 2002 Dimerization of G protein-coupled receptors: CB1 cannabinoid receptors as an example Chem. Phys. Lipids 121:83-89

Wang, H., Dey, S.K., Maccarrone, M., 2006. Jekyll and Hyde: two faces of cannabinoid signaling in male and female fertility. Endocr. Rev. 27, 427-448. 
Wenger, T., Fernández-Ruiz, J.J., Ramos, J.A.. 1999. Immunocytochemical demonstration of CB1 cannabinoid receptors in the anterior lobe of the pituitary gland. J. Neuroendocrinol. $11,873-8$.

Wenger, T., Jamali, K.A, Juaneda, C., Bascsy, E., Tramu, G., 2000. The endogenous cannabinoid, anandamide regulates anterior pituitary secretion in vitro. Addiction Biol. 5, $59-64$.

Wenger, T., Ledent, C., Csernus, V., Gerendai, I., 2001. The central cannabinoid receptor inactivation suppresses endocrine reproductive functions. Biochem. Biophys. Res. Commun. 284, 363-368.

Wiley, J.L., Martin, B.R., 2002. Cannabinoid pharmacology: implications for additional cannabinoid receptor subtypes. Chem. Phys. Lipids 121, 57-63.

Zhang, P.W., Ishiguro, H., Ohtsuki, T., Hess, J., Carillo, F., Walther, D., Onaivi, E.S., Arinami, T., Uhl, G.R., 2004. Human cannabinoid receptor 1: 5' exons, candidate regulatory regions, polymorphisms, haplotypes and association with polysubstance abuse. Mol. Psychiatry 9, 916-931. 


\section{FIGURE LEGENDS}

Fig.1 Amino acidic alignments of the N-terminal amino acidic residues of known amphibian CB1 (Accession numbers in GenBank: Rana esculenta, $\underline{\mathbf{A M 1 1 3 5 4 6}}$; Taricha granulosa, AF181894; Xenopus laevis, $\underline{\mathbf{A Y 0 9 8 5 3 2}}$. Dark box marks the less conserved region in Nterminal domain; dotted line indicates seven consecutive amino acidic residues lost in R.esculenta $; \quad$ - = single, fully conserved residues; : = conservation of strong groups; .= conservation of weak groups.

Fig.2 A) $C b 1$ and $G n R H-I$ expression profile in frog forebrain during the annual sexual cycle; analysis conducted by RT-PCR. B-C) Normalization of the signals observed by RT-PCR Data are representative of three separate experiments at least and are expressed as fold increase of the minimal GnRH-I/fpl $(c b 1 / f p 1)$ ratio observed \pm s.e.m. Different letters indicate statistically significant differences ( $p<0.05$ at least).

Fig.3 CB1 fluctuations in frog telencephalon A) and diencephalon B) during the annual sexual cycle. Data are representative of three separate experiments at least and are expressed as fold increase over the minimal CB1/ERK1 ratio observed by Western blot. observed \pm s.e.m. Different letters indicate statistically significant differences $(p<0.05$ at least). Lines represent GnRH-I content observed in brain (data from Di Matteo et al., 1996); dotted line $=$ GnRH-I accumulation; black line $=$ GnRH-I low level; grey dotted line $=$ GnRH-I release . 


\section{Acknowledgments}

Authors thank Professor Ken Mackie (University of Indiana, USA) who has kindly provided the antiserum used for Western blot.

This work has been supported by grants from the PRIN-Pierantoni 2002 and 2005; Regione Campania L.5 
R.esculenta

X. Laevis

T. granulosa

R. esculenta

X. 1aevis

T. granulosa

MKSVLDGLADTTFRTITTDLLYMGPNEVQYEDTKSDLS-KLGYYPQKLPL 49 MKS ILDGLADTTFRTI TTDLLYLGPNEVQYDDSKGDISSKLVY FPQKLPL 50 MKSILDGLADTTFRTITTDLLYMGSNDVQYEDTKGEMASKLGYFPQKLPL 50

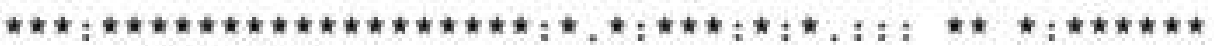
SSYOER SSLRGLுPLHEKM I IDDPLLSIP-LDQINATDFYNKSII-FKDTDDNVQC 98 SSFRRDHSPDKMIIGDDNLLSFYPLDQFNVTEFFNRSVSTFKENDDNLKC 100

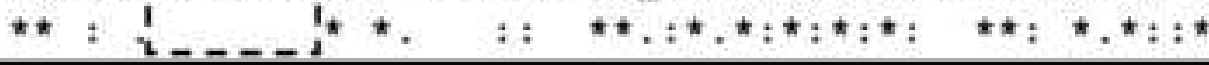

R.esculenta X. Iaevis

T. granulosa
GNNFMDMECFMILTPSQQLVIAALSI TLGTFTVLENMLVLCVI FQSRTLR 140 GKNRMDMECFMILTPSQQLVIAALSI ILGTFTVLENMLVLVVIVQSRSLR 148 GENFMDMECFMILTASQQLI IAVLSLTLGTFTVLENFLVLCVILQSRTLR 150

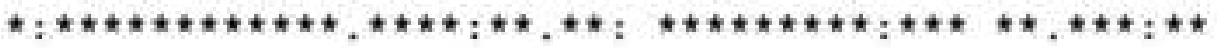


A

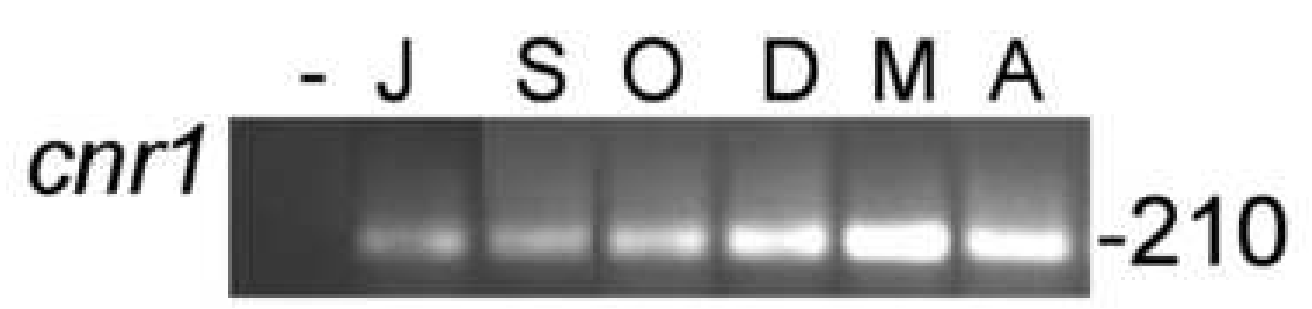

$\mathrm{GnRH}-\mathrm{I}$

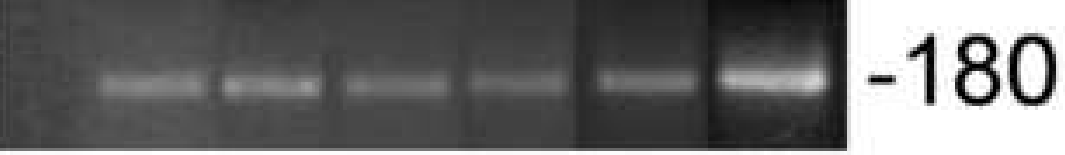

fp1

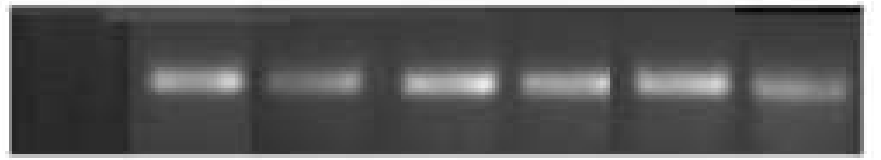

$-356$

B

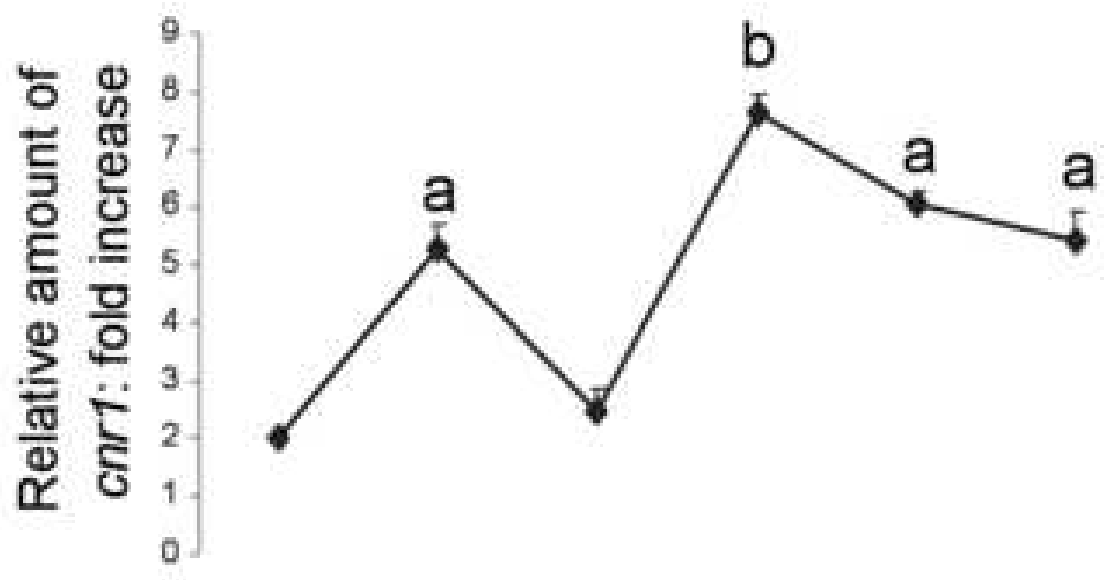

C

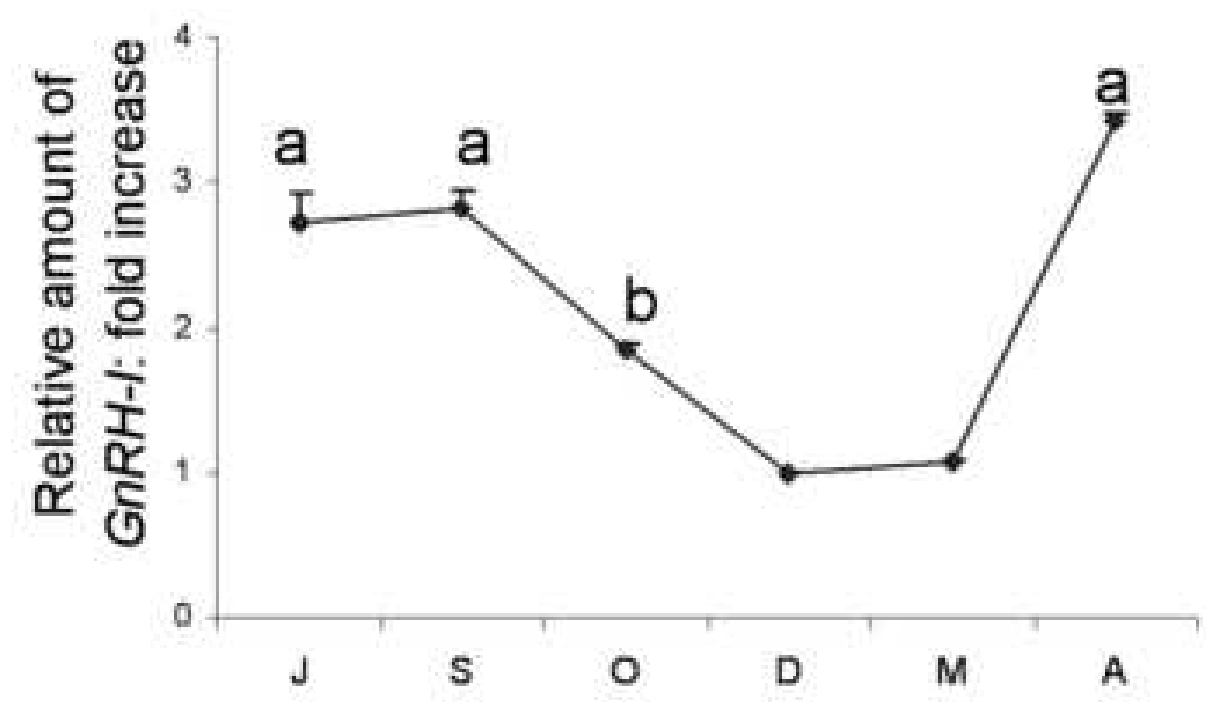

FIG.2 
A telencephalon

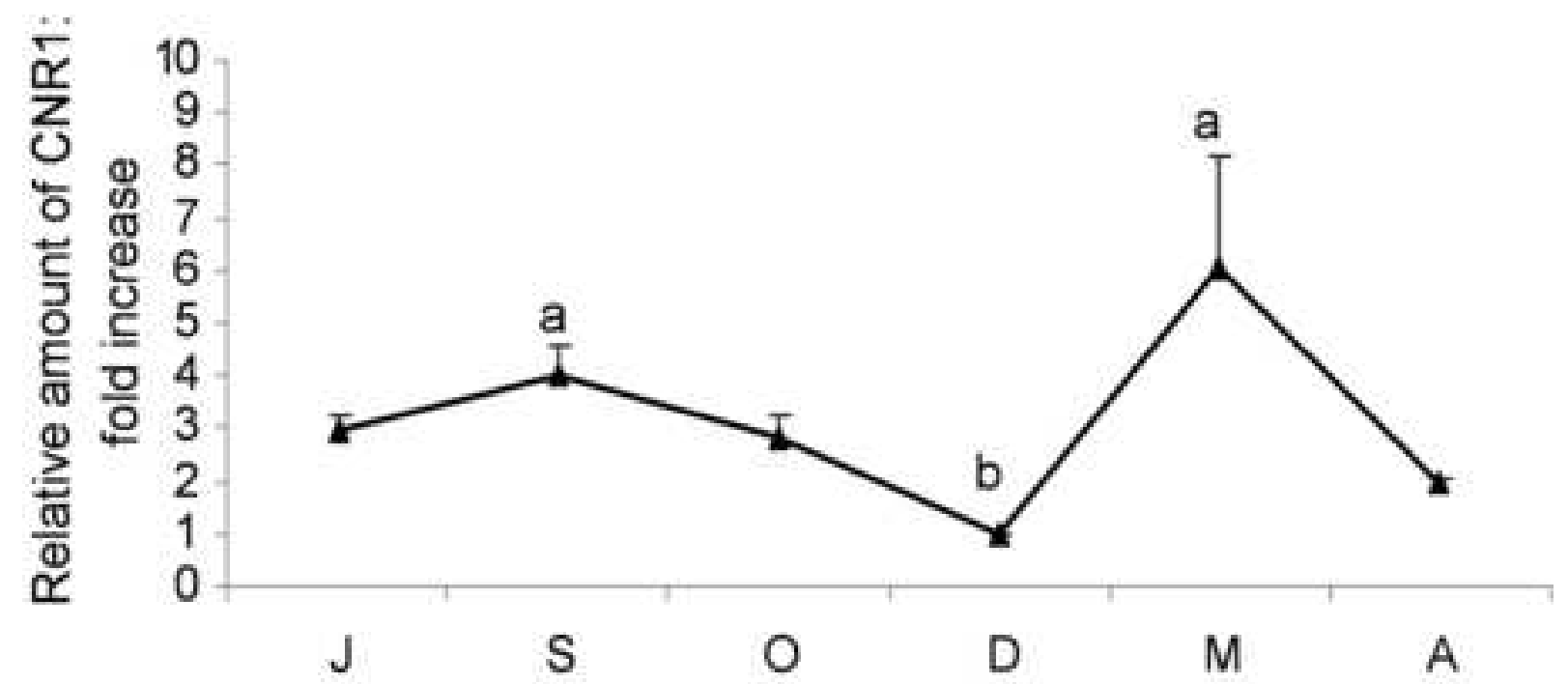

B
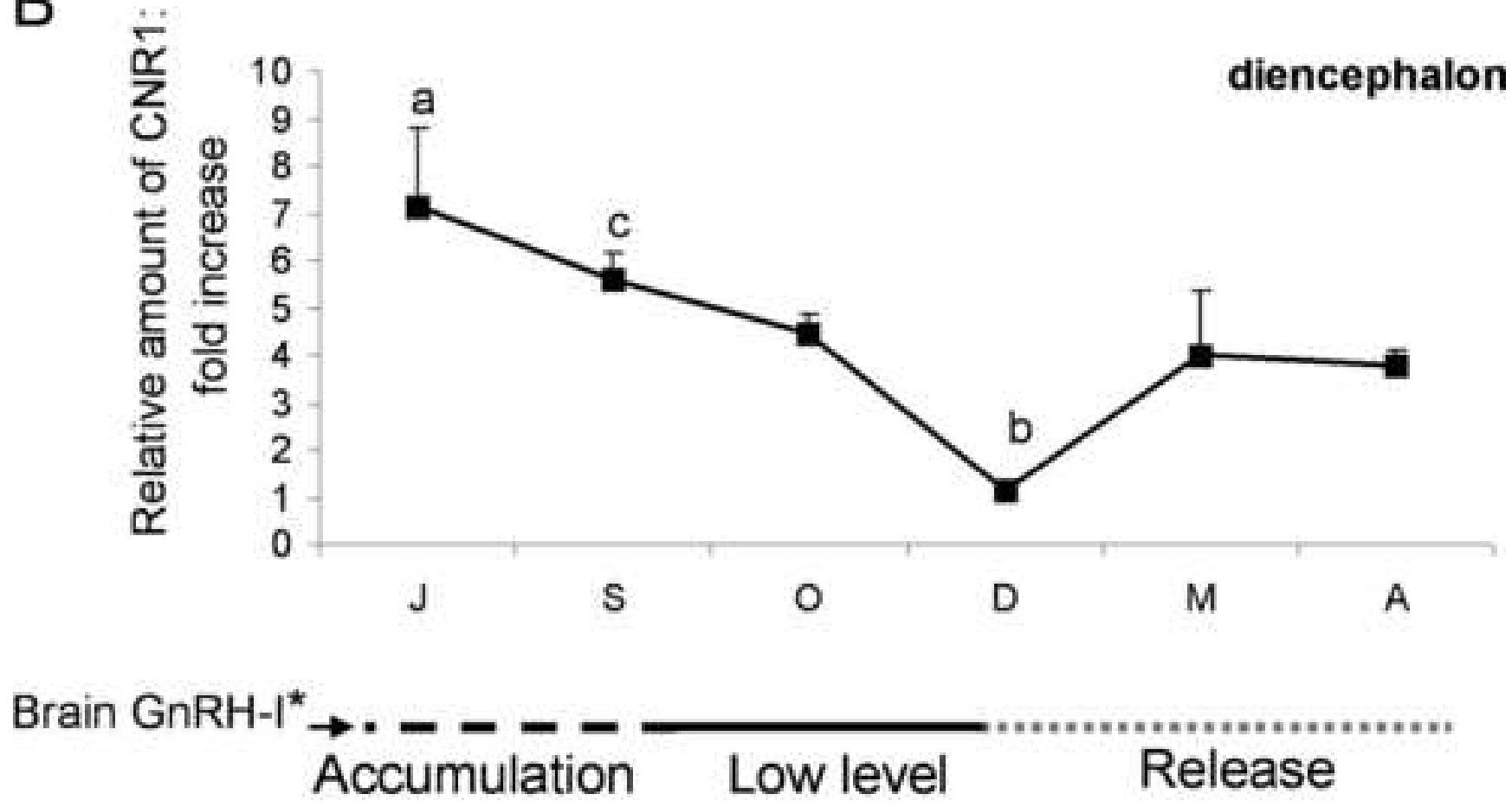

Fig 3 